\title{
Sunflower cultivation under different irrigation systems and planting spacings in the sub-middle region of São Francisco Valley
}

\author{
Cultivo do girassol com diferentes sistemas de irrigação e \\ espaçamentos de plantio no Submédio São \\ Francisco
}

\author{
Welson Lima Simões ${ }^{1 *}$; Jucicléia Soares da Silva ${ }^{2}$; Anderson Ramos de Oliveira ${ }^{1}$; \\ Amadeu Regitano Neto ${ }^{1}$; Marcos Antonio Drumond ${ }^{1}$; Jair Andrade Lima ${ }^{3}$; \\ Bruno Rodrigues do Nascimento ${ }^{4}$
}

\section{Highlights:}

Water availability and plant spacing on the development of sunflower.

Achene yield higher than the national average.

Drip irrigation and $0.55 \mathrm{~m}$ spacing ensure greater yields in Helium 251 .

Micro-sprinkler irrigation and 0.55/0.45 m spacing ensure high yields in Helium 360 .

Sprinkler irrigation and $0.45 \mathrm{~m}$ spacing ensure high yields in Helium 360 .

\begin{abstract}
The growth and yield of sunflower plants can be influenced by the plant population arrangement and the type of irrigation system adopted to meet the water requirements of the crop. This study examines the influence of different irrigation systems and spacings between planting rows on the development of sunflower cultivars for the sub-middle region of São Francisco Valley. The experiment was laid out in a randomized block design with a split-plot arrangement in which the plots consisted of three irrigation systems (drip, micro-sprinkler and sprinkler); sub-plots were represented by three spacings between planting rows $(0.65,0.55$ and $0.45 \mathrm{~m})$; and sub-sub-plots corresponded to two sunflower cultivars (Hélio 251 and Hélio 360). The following variables were analyzed: plant height; number of leaves; stem diameter; number of heads; head diameter; dry biomass of stems, leaves and heads; and achene yield. The different irrigation systems and row spacings markedly influenced the growth of the sunflower cultivars. The highest yield of cultivar Hélio 251 was obtained with the drip irrigation system and 0.55 $\mathrm{m}$ spacing. Cultivar Hélio 360 achieved the highest yields when irrigated by the micro-sprinkler system at 0.55 and $0.45 \mathrm{~m}$ spacing. In the sprinkler irrigation system, cultivar Hélio 360 obtained the highest yield at $0.45 \mathrm{~m}$ spacing.
\end{abstract}

Key words: Helianthus annuus. Population arrangement. Water availability. Yield.

\footnotetext{
1 Pesquisadores, Empresa Brasileira de Pesquisa Agropecuária, EMBRAPA Semiárido, Petrolina, PE, Brasil. E-mail: welson. simoes@embrapa.br; anderson.oliveira@embrapa.br; amadeu.regitano@embrapa.br; marcos.drumond@embrapa.br

2 Pós-Doutoranda, EMBRAPA Semiárido, Petrolina, PE, Brasil. E-mail: jucicleiass@gmail.com

3 Graduado em Ciências Biológicas, Universidade de Pernambuco, UPE, Petrolina, PE, Brasil. E-mail: jairandrade.bio@, hotmail.com

4 Discente do Curso de Ciências Biológicas, UPE, Petrolina, PE, Brasil. E-mail: brunorodrygue75@gmail.com

* Autor for correspondence
} 


\section{Resumo}

O crescimento e a produtividade de plantas de girassol podem ser influenciados pelo arranjo populacional de plantas e pelo tipo de sistema de irrigação adotado para suprir as necessidades hídricas da cultura. O objetivo com este trabalho foi avaliar a influência de diferentes sistemas de irrigação e espaçamentos entre linhas de plantio no desenvolvimento de cultivares de girassol, para a região do Submédio do Vale do São Francisco. O delineamento experimental foi em blocos casualizados dispostos em parcelas subsubdivididas, sendo as parcelas três sistemas de irrigação (gotejamento, microaspersão e aspersão), as subparcelas três espaçamentos entre linhas de plantio $(0,65 ; 0,55 ; \mathrm{e} 0,45 \mathrm{~m})$ e as subsubparcelas duas cultivares de girassol (Hélio 251 e Hélio 360). As variáveis analisadas foram: altura de plantas, número de folhas, diâmetro do caule, número de capítulos, diâmetro do capítulo, biomassa seca do caule, folhas e capítulos e produtividade de aquênios. Os diferentes sistemas de irrigação e de espaçamento entre linhas influenciaram o crescimento das cultivares de girassol de forma singular. A maior produtividade da cultivar Hélio 251 foi obtida quando submetida ao sistema de irrigação por gotejamento e ao espaçamento de $0,55 \mathrm{~m}$. A cultivar Hélio 360 irrigado pelo sistema de microaspersão, alcançou as maiores produtividades, com os espaçamentos $0,55 \mathrm{~m} \mathrm{e} 0,45 \mathrm{~m}$. No sistema de irrigação por aspersão, a cultivar Hélio 360 expressou maior produtividade no espaçamento de $0,45 \mathrm{~m}$.

Palavras-chave: Helianthus annuus. Arranjo populacional. Disponibilidade hídrica. Produtividade.

\section{Introduction}

Sunflower (Helianthus annuus L.), a member of the family Asteraceae, is a highly adaptable domesticated species cultivated in several countries due to its multiple uses and applications as well as socioeconomic importance. In addition to being employed as an ornamental plant and in honey production, the species has great potential for the production of oil of excellent quality, which can be used in human nutrition, in the formulation of medicinal and nutraceutical products and in the biofuel industry, as the oil can be converted to biodiesel. Furthermore, sunflower plants constitute excellent material for the production of forage, silage and meals for animal feeding (Freitas et al., 2012).

In 2018, the sunflower crop yield in Brazil was $1,588 \mathrm{~kg} \mathrm{ha}^{-1}$ (Companhia Nacional de Abastecimento [CONAB], 2018). Under proper management conditions, this value can reach up to 1,800 to 2,200 $\mathrm{kg} \mathrm{ha}^{-1}$ (Backer, Souza, Balbinot, Gallotti, \& Bavaresco, 2008; Heckler, 2002; Porto, Carvalho, \& Pinto, 2007). When irrigated, the sunflower crop has a grain yield generally between 2,200 to 3,000 $\mathrm{kg} \mathrm{ha}^{-1}$ (Biscaro et al., 2008;
Flagella, Rotunno, Tarantino, Di Caterina, \& De Caro, 2002; Silva, Faria, Morais, Andrade, \& Lima, 2007; Simões, Drumond, Oliveira, Gonçalves, \& Guimarães, 2018; Smiderle, Mourão, Jr., \& Gianluppi, 2005). However, there are records of grain yields exceeding $6,300 \mathrm{~kg} \mathrm{ha}^{-1}$ under irrigation (Anastasi, Santonoceto, Giuffre, Sortino, \& Abbate, 2010; Goksoy, Demir, Turan, \& Dagustu, 2004; E. P. Gomes et al., 2012; Karam et al., 2007; Simões et al., 2016).

The sunflower plant has a rapid annual growth, with straight, subwoody, non-branched stems and great capacity to adapt to different environmental conditions thanks to characteristics such as drought, cold and heat resistance (D. P. Gomes, Bringel, Moraes, Gomes, \& Leite, 2006). It develops in almost the entire Brazilian territory, adapting easily to low water availability in regions where low and irregular rainfalls are a common occurrence (Travassos et al., 2012). In this respect, Hussain et al. (2018) highlighted that the species has been cultivated in arid and semi-arid regions, oftentimes with supplementary irrigation, despite being affected by environmental restrictions such as high temperatures and water deficit. 
In the period between flowering and achene filling, sunflowers are highly sensitive to water restriction. This can influence the final product, causing a significant reduction in achene yield and in the quality of the extracted oil (Hussain et al., 2018). The flexibility of the crop to the semi-arid climate and its low sensitivity to the photoperiod enable its growth at any time of the year (Cavalcante et al., 2013).

According to Castro and Farias (2005), the need for water for the cultivation of sunflower increases as the plant develops. This requirement starts at values around 0.5 to $0.7 \mathrm{~mm} \mathrm{day}^{-1}$, during the phase from sowing to emergence, to a maximum of 6 to $8 \mathrm{~mm} \mathrm{day}^{-1}$ at flowering and grain filling. Therefore, the use of irrigation in semi-arid regions is necessary, given the irregular distribution of rainfall. Water requirements can be met with around $200 \mathrm{~mm}$ to more than $900 \mathrm{~mm}$ per crop cycle. When well-distributed throughout the cycle, water volumes of 400 to $500 \mathrm{~mm}$ result in high grain, oil and dry matter yields, demonstrating the feasibility of implementing irrigation systems (E. P. Gomes et al., 2012; Simões et al., 2016, 2018).

In addition to the water factor, other variables influence the growth, development and yield of sunflower. Among them, the spacing between planting rows is an important factor to be considered in the cultivation system. As stated by Khan and Akmal (2016), the arrangement of sunflower plants must be well-defined so that the crop reaches optimum production, making the most of its resources (solar radiation and assimilation of nutrients). Poursakhi and Khajehpour (2012) found that the seed yield and oil percentage of sunflower plants increased with larger spacings, whereas yield per unit area decreased as the space between rows was augmented.

The response of plants to the spacing between rows can differ due to interception of solar radiation or due to intraspecific competition for water and nutrients, which may also be related to the cultivar and the irrigation system adopted. In view of these factors, technological practices that adjust the sunflower production cycle with less restrictive environmental conditions to the development of the crop are necessary. Some of these strategies are the use of short and adapted genotypes, adequate spacing and efficient irrigation systems, aiming to overcome the water deficit in the crop and make rational use of water. The use of reduced spacing in sunflower cultivation provides several benefits such as better distribution of plants in the cultivation area and greater interception of light by these plants, reducing the competition between them for natural resources (Andrade, Calvino, Cirilo, \& Barbieri, 2002; Zarea, Ghalavand, \& Daneshian, 2005).

This study examines the influence of different irrigation systems and spacings between planting rows on the growth and yield of sunflower cultivars grown in the sub-middle region of São Francisco Valley.

\section{Material and Methods}

The study was carried out at the Bebedouro Experimental Field, belonging to Embrapa Semiárido, located in the municipality of Petrolina - PE, Brazil (909' S, 40²2' W, 365.5 m above sea level). According to the Köppen classification system, the climate of the region is a semi-arid tropical BSWh type, as described by Reddy and Amorim (1983). Rainfall is concentrated between the months of November and April, with an average annual precipitation of $400 \mathrm{~mm}$, distributed irregularly. The average annual temperature is 26.5 ${ }^{\circ} \mathrm{C}$, ranging between 21 and $32{ }^{\circ} \mathrm{C}$, with an average annual evaporation of approximately $2,000 \mathrm{~mm}$, average annual relative humidity of $67.8 \%, 3,000$ $\mathrm{h}$ of sunlight and wind speed of $2.3 \mathrm{~m} \mathrm{~s}^{-1}$ (P. C. G. Silva et al., 2010).

The soil of the experimental area was classified as a Quartz-sand Neosol, with $73 \%$ sand, $19 \%$ silt and $8 \%$ clay. In addition to soil classification, chemical analysis was carried out for fertilization recommendations. Prior to planting the sunflower cultivars, the soil was plowed and harrowed. 
The experiment was laid out in a split-plot randomized-block design in which the plots were represented by three irrigation systems (drip, microsprinkler and sprinkler), the subplots consisted of three spacings between planting rows $(0.65$, 0.55 and $0.45 \mathrm{~m}$ ) and the sub-sub-plots were two sunflower cultivars (Hélio 251 and Hélio 360), with three replicates. A spacing of $12 \mathrm{~m}$ between the plots was adopted to avoid the influence of treatments on neighboring plots.

Sunflower cultivars were sown with plants spaced $0.30 \mathrm{~m}$ apart in the planting rows. The experimental plots consisted of 14 six-meter rows, with the four central rows being considered usable area.

The drip irrigation system was arranged by planting row, with a spacing of $0.30 \mathrm{~m}$ between drippers, which was determined after the wet bulb test. Micro-sprinklers were spaced 2.5 mapart. Lastly, in the sprinkler system, the emitters were spaced $12 \mathrm{~m}$ apart. The irrigation amounts were applied considering $100 \%$ of the crop evapotranspiration (ETc); the reference evapotranspiration (ETo) was obtained using data from a meteorological station installed near the experimental area, by the PenmanMonteith method modified by Allen, Pereira, Raes and Smith (1998), whose expression is described as follows:

$$
E T_{0}=\frac{0.408 \Delta\left(R_{n}-G\right)+\gamma\left(\frac{900 U_{2}}{T+273}\right)\left(e_{a}-e_{S}\right)}{\Delta+\gamma\left(1+0.34 U_{2}\right)}
$$

where $\mathrm{R}_{\mathrm{n}}$ is the radiation balance at the surface, in $\mathrm{MJ} \mathrm{m} \mathrm{m}^{-2} \mathrm{~d}^{-1}$; $\mathrm{G}$ is the heat flow in the soil, in $\mathrm{MJ} \mathrm{m}^{-2}$ $\mathrm{d}^{-1} ; \mathrm{T}$ is the air temperature at a height of $2.0 \mathrm{~m}$, in ${ }^{\circ} \mathrm{C}$; $\mathrm{U}_{2}$ is the wind speed at a height of $2.0 \mathrm{~m}$, in $\mathrm{m}$ $\mathrm{s}^{-1} ; e_{s}$ is the vapor saturation pressure, in $\mathrm{kPa} ; e_{a}$ is the current vapor pressure of the air, in $\mathrm{kPa} ;\left(e_{a}-e_{s}\right)$ is the vapor pressure deficit, in $\mathrm{kPa} ; \Delta$ is the slope of the saturation vapor pressure curve, in $\mathrm{kPa}^{\circ} \mathrm{C}^{-1}$; and $\gamma$ is the psychrometric constant, in $\mathrm{kPa}^{\circ} \mathrm{C}^{-1}$.

The crop coefficients $(\mathrm{Kc})$ used were those suggested by Food and Agriculture Organization of the United Nations [FAO] (2002), with mean values of $0.35,0.75,1.10,0.75$ and 0.4 for the initial, vegetative, flowering, grain-filling and physiological-maturity stages, respectively. To ensure that the plants would receive the amount of water recommended for each type of irrigation system and plant spacing, the volumes of water applied per unit area were calculated using the following mathematical expression:

$$
V_{a=\frac{E T_{c} \times A_{u}}{E_{a}}}
$$

where $V_{a}$ is the volume of water applied per unit area (L); $A_{u}$ is the maximum area occupied by a linear meter of a plant row $\left(\mathrm{m}^{2}\right)$; and $E_{a}$ is the water application efficiency of the irrigation system (in decimals), which was determined after the irrigation systems were installed, following the methodology described by Keller and Bliesner (1990).

At 90 days after sowing, four plants per plot were selected at random in the planting area to measure the following variables: plant height, number of leaves and heads, stem and head diameter, achene yield and dry biomass of stems, leaves and heads. Plant height was determined using a tape measure from the soil to the plant apex. The measurements of stem (at the neck of the plant) and head diameter were obtained using a caliper. All plants in the usable area were harvested to estimate achene yield and then weighed on a scale with $0.01 \mathrm{~g}$ precision. Subsequently, to determine the dry biomass of stems, leaves and head, the material was packed in paper bags and dried in a forced-air oven at a temperature of $65^{\circ} \mathrm{C}$ until reaching constant weight. Afterwards, the material was weighed on a scale with a $0.01 \mathrm{~g}$ precision.

Data were subjected to analysis of variance and means were compared by Tukey's test at 5\% significance, using Sisvar 5.0 statistical software. Significant interactions were decomposed. Variables that did not show to be significantly affected by the interactions were interpreted based on the main effects. 


\section{Results and Discussion}

Analysis of variance revealed a triple interaction effect between cultivars, irrigation systems and spacings for the traits of achene yield and dry biomass of stems, leaves and heads. Plant height was significantly affected by the interaction between cultivars and irrigation systems. A cultivar $\times$ spacing interaction effect was detected for number of heads, whereas head diameter was influenced by the interaction between irrigation systems and spacings. The analysis indicated significance in at least one source of variation for number of leaves and stem diameter.

According to the triple interaction, in the drip irrigation system, cultivar Hélio 251 had the highest average achene yield at $0.55 \mathrm{~m}$ spacing $(7,756.68$ $\mathrm{kg} \mathrm{ha}^{-1}$ ) (Table 1). With the micro-sprinkler system, when grown at the 0.55 and $0.45 \mathrm{~m}$ spacings, cultivar Hélio 360 reached average achene yields of 7,068.07 and 7,096.61 $\mathrm{kg} \mathrm{ha}^{-1}$, respectively, which are higher values than those obtained with $0.65 \mathrm{~m}$ spacing. Cultivar Hélio 360 obtained higher yields at $0.45 \mathrm{~m}$ spacing in the sprinkler irrigation system, reaching an average of 7,163.29 $\mathrm{kg} \mathrm{ha}^{-1}$; however, no significant difference was detected in comparison with Hélio $251\left(5,992.64 \mathrm{~kg} \mathrm{ha}^{-1}\right)$. The irrigation systems had a significant effect on all analyzed variables, but the drip irrigation system associated with 0.55 and $0.45 \mathrm{~m}$ spacing provided greater growth and yield to sunflower cultivars Hélio 251 and Hélio 360 in the sub-middle region of the São Francisco Valley. The drip system likely maintained greater soil moisture, given the proximity of the drippers to the soil surface, which reduces evaporation losses. According to A. G. Silva, Pires, Morães, Oliveira and Carvalho (2009), low yields in sunflower occur due to the reduction of water availability in the soil, which affects the growth of heads and achenes. In addition to the drip effect, the smaller planting spacings for cultivars Hélio 251 and Hélio 360 also tended to increase achene yield by providing higher densities. These results are similar to those found by Ahmed, Ahmed and Ahmed (2006), and Li, Qu, Chen, Yang and Huang (2019), who investigated the planting density of drip-irrigated sunflower and observed that smaller plant spacings (higher density) tend to significantly increase seed production.

\section{Table 1}

Achene yield ( $\left.\mathrm{kg} \mathrm{ha}^{-1}\right)$ of sunflower cultivars grown under different irrigation systems and spacings. Petrolina, PE

\begin{tabular}{|c|c|c|c|}
\hline Systems /Cultivars* & & Spacings & \\
\hline Drip & $0.65 \mathrm{~m}$ & $0.55 \mathrm{~m}$ & $0.45 \mathrm{~m}$ \\
\hline Hélio 251 & $3104.57 \mathrm{bA} \gamma$ & $7756.68 \mathrm{aA} \alpha$ & $5326.28 \mathrm{aA} \beta$ \\
\hline Hélio 360 & $5122.96 \mathrm{aA} \alpha$ & $5640.06 \mathrm{bA} \alpha$ & $5637.72 \mathrm{aA} \alpha$ \\
\hline \multicolumn{4}{|l|}{ Micro-sprinkler } \\
\hline Hélio 251 & $4502.80 \mathrm{aA} \alpha$ & $4390.96 \mathrm{bB} \alpha$ & $5147.05 \mathrm{bA \alpha}$ \\
\hline Hélio 360 & $4080.64 \mathrm{aA} \beta$ & $7068.07 \mathrm{aA} \alpha$ & $7096.61 \mathrm{aA} \alpha$ \\
\hline \multicolumn{4}{|l|}{ Sprinkler } \\
\hline Hélio 251 & $4190.00 \mathrm{aA} \alpha$ & $5077.24 \mathrm{aB} \alpha$ & $5992.64 \mathrm{aA} \alpha$ \\
\hline Hélio 360 & $5430.24 \mathrm{aA} \alpha$ & $5445.07 \mathrm{aA} \alpha$ & $7163.29 \mathrm{aA} \alpha$ \\
\hline Coefficient of variation (\%) & 18.84 & & \\
\hline
\end{tabular}


Regardless of the treatments to which the sunflower plants were subjected, their yield reached values above the national average, which is 1,588 $\mathrm{kg} \mathrm{ha}^{-1}$ (CONAB, 2018). This fact can be explained by the water availability provided by irrigation with the different systems used, coupled with the adaptability of the crop to the high insolation that affects the region. These conditions favored the crop and demonstrate the productive potential of the semiarid region, where the crop has great potential if well-managed with the aid of irrigation.

The average achene yields obtained with the drip irrigation system for cultivars Hélio 251 and Hélio 360 corroborate those reported by Simões et al. (2016), who evaluated the influence of different irrigation amounts and dripper arrangements on the morphophysiological traits of sunflower cultivars and obtained yields between 2,500 and 5,000 $\mathrm{kg} \mathrm{ha}^{-1}$ in cultivar Hélio 251 and between 4,000 and 5,000 $\mathrm{kg} \mathrm{ha}^{-1}$ in Hélio 360. Some studies have shown that the increase in sunflower production provided by irrigation varies from 30 to $100 \%$, with values greater than $70 \%$ in semiarid regions (Anastasi et al., 2010; Flagella et al., 2002; Goksoy et al., 2004; M. L. O. Silva et al., 2007).
Significant differences were found for stem dry biomass in sunflower cultivars grown using different irrigation systems and spacings (Table 2 ). With the drip irrigation system, cultivar Hélio 360 obtained the largest stem dry biomass at 0.65 $\mathrm{m}$ spacing, reaching an average of $202.28 \mathrm{~g}$. With the micro-sprinkler system, cultivar Hélio 360 obtained average stem biomass values between 194.20 and $197.41 \mathrm{~g}$ at the 0.55 and $0.45 \mathrm{~m}$ spacings, respectively. Cultivar Hélio 251 obtained the highest average stem dry biomass of 264.74 $\mathrm{g}$, at $0.45 \mathrm{~m}$ spacing, with the sprinkler irrigation system. As with yield, irrigation systems benefit the accumulation of dry biomass of stems in sunflower plants, as they favor stomatal opening and $\mathrm{CO}_{2}$ absorption by increasing water availability in the soil. Combined with high radiation, this increased water availability provides higher photosynthetic rates, resulting in increased biomass production (Taiz, Zeiger, Møller, \& Murphy, 2017). The positive aspects of water availability in the sunflower crop were also highlighted by E. P. Gomes et al. (2012), who investigated the yield, oil content and stem dry biomass in cultivar Aguará 4 under different amounts of supplementary irrigation and observed a linear increase in all evaluated stages.

Table 2

Dry biomass of stems (g) of sunflower cultivars grown under different irrigation systems and spacings. Petrolina, PE

\begin{tabular}{|c|c|c|c|}
\hline Systems /Cultivars* & & Spacings & \\
\hline Drip & $0.65 \mathrm{~m}$ & $0.55 \mathrm{~m}$ & $0.45 \mathrm{~m}$ \\
\hline Hélio 251 & $156.24 \mathrm{bB} \alpha$ & $143.79 \mathrm{aB} \alpha \beta$ & $104.49 \mathrm{aC} \gamma$ \\
\hline Hélio 360 & $202.28 \mathrm{aAB} \alpha$ & $146.08 \mathrm{aB} \beta$ & $142.70 \mathrm{aB} \beta$ \\
\hline \multicolumn{4}{|l|}{ Micro-sprinkler } \\
\hline Hélio 251 & $174.63 \mathrm{aB} \alpha$ & $150.46 \mathrm{bB} \alpha$ & $187.52 \mathrm{aB} \alpha$ \\
\hline Hélio 360 & $163.61 \mathrm{aB} \alpha$ & $194.20 \mathrm{aA} \alpha$ & $197.41 \mathrm{aA} \alpha$ \\
\hline \multicolumn{4}{|l|}{ Sprinkler } \\
\hline Hélio 251 & $232.29 \mathrm{aA} \alpha \beta$ & $215.10 \mathrm{aA} \beta$ & $264.74 \mathrm{aA} \alpha$ \\
\hline Hélio 360 & $237.25 \mathrm{aA} \alpha$ & $175.32 \mathrm{bAB} \beta$ & $195.98 \mathrm{bA} \alpha \beta$ \\
\hline Coefficient of variation ( $\%)$ & & 12.81 & \\
\hline
\end{tabular}


The dry biomass of leaves, in turn, was influenced by the different irrigation systems, cultivars and spacings (Table 3 ). The drip irrigation system influenced the dry biomass of leaves of cultivar Hélio 251 at $0.65 \mathrm{~m}$ spacing, which reached the highest average of $254.81 \mathrm{~g}$. With the micro-sprinkler system, cultivar Hélio 360 grown at the spacings of 0.55 and $0.45 \mathrm{~m}$ showed mean leaf dry biomasses between 209.80 and $196.89 \mathrm{~g}$, respectively. However, cultivar Hélio 251 obtained a larger leaf dry biomass at $0.45 \mathrm{~m}$ spacing in the micro-sprinkler and sprinkler irrigation systems, reaching 239.93 and 245.09 g, respectively. These results corroborate those described by $\mathrm{Li}$ et al. (2019), who observed that denser spacings increased leaf biomass in sunflower plants.

Table 3

Dry biomass of leaves (g) of sunflower cultivars grown under different irrigation systems and spacings. Petrolina, PE

\begin{tabular}{cccc}
\hline Systems /Cultivars* & Spacings & \\
\hline Drip & $0.65 \mathrm{~cm}$ & $0.55 \mathrm{~cm}$ & $0.45 \mathrm{~cm}$ \\
\hline Hélio 251 & $148.44 \mathrm{aB} \alpha$ & $215.02 \mathrm{aA} \alpha$ & $254.81 \mathrm{aA} \alpha$ \\
Hélio 360 & $197.33 \mathrm{aAB} \alpha$ & $171.38 \mathrm{aB} \alpha$ & $246.02 \mathrm{aA} \alpha$ \\
\hline Micro-sprinkler & & & $239.93 \mathrm{aA} \alpha$ \\
Hélio 251 & $137.80 \mathrm{sB} \alpha$ & $153.78 \mathrm{bB} \beta$ & \\
Hélio 360 & $148.98 \mathrm{aA} \alpha$ & $209.80 \mathrm{aA} \alpha$ & $245.09 \mathrm{aA} \alpha$ \\
\hline Sprinkler & & & $208.48 \mathrm{aAA} \alpha$ \\
\hline Hélio 251 & $100.61 \mathrm{aC} \alpha$ & $176.10 \mathrm{aB} \alpha \beta$ & \\
Hélio 360 & $149.19 \mathrm{aA} \alpha$ & $162.57 \mathrm{aA} \alpha$ & 16.33
\end{tabular}

* Uppercase letters in the columns refer to differences between cultivars within each combination of systems and spacings; lowercase letters in the columns refer to differences between systems within each combination of cultivars and spacings; and Greek letters in the rows refer to differences between spacings within each combination of cultivars and irrigation systems, according to Tukey's test at $\mathrm{p}<0.05$.

The dry biomass of heads per sunflower plant was also influenced by the different irrigation systems, cultivars and spacings (Table 4). The drip-irrigation system influenced this variable in cultivars Hélio 251 and 360, which reached the highest means, of 419.03 and $434.70 \mathrm{~g}$, respectively, at $0.45 \mathrm{~m}$ spacing. In the micro-sprinkler system, cultivars Hélio 251 and 360 grown at $0.45 \mathrm{~m}$ spacing obtained average dry biomasses of heads of 361.97 and $382.36 \mathrm{~g}$, respectively. Lastly, in the sprinkler irrigation system, cultivars Hélio 251 and 360 reached the largest dry biomass of heads at $0.45 \mathrm{~m}$ spacing (345.62 and 290.18 g, respectively). At 0.55 m spacing, cultivar Hélio 360 obtained the largest dry biomass of heads in the sprinkler irrigation system, averaging $297.21 \mathrm{~g}$. The response shown by dry biomass of heads to the spacings was similar to that observed for stem dry biomass, since smaller planting spacings in cultivars Hélio 251 and Hélio 360 , under irrigation, tended to result in larger dry biomasses of heads, corroborating the findings of $\mathrm{Li}$ et al. (2019).

Plant height was significantly influenced by the interaction between cultivars and irrigation systems. However, the difference was observed only between cultivars in the micro-sprinkler irrigation system, in which the plants of cultivar Hélio 360 were taller than those of cultivar Hélio 251 (Table 5). Variations in height can be attributed to the intrinsic characteristics of each cultivar. Nonetheless, differences can be observed depending on the type 
of irrigation used, as the micro-sprinkler provides a greater volume of wet soil for exploration of the root system than the drip system, in addition to the formation of a microclimate, which may be more favorable to the plants of cultivar Hélio 360 than plots with drippers and sprinklers. When the same traits were evaluated between the drip and sprinkler irrigation systems, no significant difference was observed. However, studies led by Joner et al.
(2011) and Santos, Barros, Capone, Ferraz and Fidelis (2012) with the same cultivars did not reveal differences in height between the cultivars. Simões et al. (2016) investigated the influence of different irrigation amounts and dripper arrangements on morphophysiological traits of sunflower cultivars and also did not find a significant effect on plant height.

\section{Table 4}

Dry biomass of heads (g) of sunflower cultivars grown under different irrigation systems and spacings. Petrolina, PE

\begin{tabular}{cccc}
\hline Systems /Cultivars* $^{*}$ & \multicolumn{1}{l}{ Spacings } \\
\hline Drip & $0.65 \mathrm{~cm}$ & $0.55 \mathrm{~cm}$ & $0.45 \mathrm{~cm}$ \\
\hline Hélio 251 & $206.73 \mathrm{aC} \alpha$ & $329.93 \mathrm{aB} \alpha$ & $419.03 \mathrm{aA} \alpha$ \\
Hélio 360 & $288.72 \mathrm{aB} \alpha$ & $252.00 \mathrm{bB} \alpha$ & $434.70 \mathrm{aA} \alpha$ \\
\hline Micro-sprinkler & & & $361.97 \mathrm{aA} \alpha$ \\
\hline Hélio 251 & $211.86 \mathrm{aB} \alpha$ & $223.27 \mathrm{aB} \beta$ & $382.36 \mathrm{aA} \alpha$ \\
\hline Hélio 360 & $220.31 \mathrm{aB} \alpha$ & $223.87 \mathrm{aB} \alpha$ & $345.62 \mathrm{aA} \alpha$ \\
\hline Sprinkler & & & $290.18 \mathrm{aA} \beta$ \\
\hline Hélio 251 & $142.68 \mathrm{aB} \alpha$ & $257.43 \mathrm{aA} \alpha \beta$ & $297.21 \mathrm{aA} \alpha$ \\
\hline
\end{tabular}

Coefficient of variation $(\%)$

15.67

* Uppercase letters in the columns refer to differences between cultivars within each combination of systems and spacings; lowercase letters in the columns refer to differences between systems within each combination of cultivars and spacings; and Greek letters in the rows refer to differences between spacings within each combination of cultivars and irrigation systems, according to Tukey's test at $\mathrm{p}<0.05$.

Table 5

Plant height $(\mathrm{cm})$ of sunflower cultivars grown under different irrigation systems. Petrolina, PE

\begin{tabular}{cccc}
\hline \multirow{2}{*}{ Cultivars* } & \multicolumn{3}{c}{ Irrigation systems } \\
\cline { 2 - 4 } & Drip & Micro-sprinkler & Sprinkler \\
\hline Hélio 251 & $147.38 \mathrm{aA}$ & $139.07 \mathrm{bA}$ & $144.06 \mathrm{aA}$ \\
Hélio 360 & $153.64 \mathrm{aA}$ & $162.84 \mathrm{aA}$ & $154.94 \mathrm{aA}$ \\
\hline
\end{tabular}

Coefficient of variation $(\%)$

12.43

* Means in the same column followed by the same lowercase letter are not statistically different; means in the same row followed by the same uppercase letter are not statistically different, according to Tukey's test at $\mathrm{p}<0.05$.

Cultivar Hélio 251 produced more heads than cultivar Hélio 360 when the spacings of 0.65 and 0.55 $\mathrm{m}$ between planting rows were adopted. However, at $0.45 \mathrm{~m}$ spacing, there was no difference in the number of heads (Table 6). Additionally, as shown in Table 6 , that the spacing of $0.45 \mathrm{~m}$ between rows provided a greater number of heads to cultivar Hélio 360 when compared with the spacings of 0.65 and $0.55 \mathrm{~m}$. Cultivar Hélio 251 produced fewer heads than Hélio 360 when the spacing of $0.45 \mathrm{~m}$ between 
planting rows was used, with the smaller spacing favoring competition between plants in cultivar Hélio 251, consequently promoting a reduction in number of heads. Backer et al. (2008) evaluated the performance of sunflower cultivars in two off-season (safrinha) crops in the northern plateau of the state of Santa Catarina and observed a reduction from 0.97 to 0.58 in the average number of sunflower heads between one experiment and another. However, the authors did not report significant differences between cultivars. For Backer et al. (2008), the number of heads per plant was a determining factor for yield in the second planting season. The authors highlighted that a lower number of heads is related to climatic factors that negatively influence the development of the crop.

Table 6

Average number of heads per sunflower plant grown under different irrigation systems and spacings. Petrolina, PE

\begin{tabular}{cccc}
\hline \multirow{2}{*}{ Cultivars* } & \multicolumn{3}{c}{ Spacings } \\
\cline { 2 - 4 } & $0.65 \mathrm{~m}$ & $0.55 \mathrm{~m}$ & $33.45 \mathrm{~m}$ \\
\hline Hélio 251 & $34.00 \mathrm{aA}$ & $33.56 \mathrm{aA}$ & $32.89 \mathrm{aA}$ \\
\hline Hélio 360 & $28.78 \mathrm{bB}$ & $30.78 \mathrm{bAB}$ & \\
\hline Coefficient of variation (\%) & & 6.33 & \\
\hline
\end{tabular}

* Means in the same column followed by the same lowercase letter are not statistically different; means in the same row followed by the same uppercase letter are not statistically different, according to Tukey's test at $\mathrm{p}<0.05$.

There was an interaction effect between irrigation systems and spacings, with a significant difference observed for head diameter. The treatment formed by the micro-sprinkler system and the spacing of
$0.65 \mathrm{~m}$ provided the largest head diameter in the sunflower plant, whose average was superior to that obtained with the other evaluated spacings (Table 7).

Table 7

Average head diameter of sunflower plants grown under different irrigation systems and spacings. Petrolina, PE

\begin{tabular}{cccc}
\hline \multirow{2}{*}{ Systems* } & \multicolumn{3}{c}{ Spacings } \\
\cline { 2 - 4 } & $0.65 \mathrm{~m}$ & $0.55 \mathrm{~m}$ & $0.45 \mathrm{~m}$ \\
\hline Drip & $15.54 \mathrm{bA}$ & $14.46 \mathrm{aA}$ & $14.47 \mathrm{aA}$ \\
Micro-sprinkler & $18.73 \mathrm{aA}$ & $14.79 \mathrm{aB}$ & $15.75 \mathrm{aB}$ \\
Sprinkler & $16.70 \mathrm{abA}$ & $16.31 \mathrm{aA}$ & $13.74 \mathrm{aB}$ \\
\hline Coefficient of variation $(\%)$ & & 10.80 & \\
\hline
\end{tabular}

* Means in the same column followed by the same lowercase letter are not statistically different; means in the same row followed by the same uppercase letter are not statistically different, according to Tukey's test at $\mathrm{p}<0.05$.

Number of leaves and stem diameter of the sunflower plants were influenced by the evaluated irrigation systems (Table 8). The highest number of leaves per plant and the largest stem diameter were obtained using the micro-sprinkler system. The number of leaves per plant (27.76) was close to the 27.4 observed by Schwerz, Jakelaitis, Teixeira, Soares and Tavares (2015), who evaluated the production of sunflower grown with and without supplementary sprinkler irrigation after soybean, maize and Brachiaria brizantha cv. Marandu crops. 
The irrigation systems also influenced the stem diameter of the plants, with the micro-sprinkler and sprinkler systems contributing to equal means. However, there was a significant difference in stem diameter between micro-sprinkler $(2.54 \mathrm{~cm})$ and drip irrigation $(2.20 \mathrm{~cm})$. Research results prove the importance of irrigation in increasing the growth, development and grain yield of several sunflower cultivars (e.g. plant height (Gusmão et al., 2018), stem diameter and leaf area (Guedes, Santos, Chaves, Campos, \& Lima, 2013); Gusmão et al., 2018) and achene yield (Acosta, 2009; Gusmão et al., 2018). Conversely, Schwerz et al. (2015) found no statistical differences for stem diameter in sunflower grown with and without irrigation after the soybean, maize and Brachiaria brizantha cv. Marandu crops, reporting $2.17 \mathrm{~cm}$ as the highest mean, in cultivar Aguará 6.

\section{Table 8}

Average number of leaves and average stem diameter of sunflower plants grown under different irrigation systems. Petrolina, PE

\begin{tabular}{ccc}
\hline Systems* $^{*}$ & Number of leaves & Stem diameter $(\mathrm{cm})$ \\
\hline Drip & $27.82 \mathrm{~b}$ & $2.20 \mathrm{~b}$ \\
Micro-sprinkler & $29.40 \mathrm{a}$ & $2.54 \mathrm{a}$ \\
Sprinkler & $27.76 \mathrm{~b}$ & $2.41 \mathrm{ab}$ \\
\hline Coefficient of variation $(\%)$ & 6.02 & 13.76
\end{tabular}

* Means in the same column followed by the same lowercase letter are not statistically different, according to Tukey's test at $\mathrm{p}<0.05$.

\section{Conclusions}

Different irrigation systems and row spacings influence the growth of sunflower cultivars. The drip irrigation system associated with $0.55 \mathrm{~m}$ spacing provides the greatest yield to cultivar Hélio 251. In cultivar Hélio 360, maximum yield is achieved with irrigation by the micro-sprinkler system with 0.55 and $0.45 \mathrm{~m}$ spacing and with the sprinkler system associated with $0.45 \mathrm{~m}$ spacing.

\section{References}

Acosta, J. F. (2009). Consumo hídrico da cultura do girassol irrigada na região da Chapada do Apodi $R N$. Dissertação de mestrado, Universidade Federal de Campina Grande, Campina Grande, PB, Brasil.

Ahmed, F. E., Ahmed, B. E. A., \& Ahmed, M. F. (2006). Effect of irrigation interval and planting density on seed and oil yields of a sunflower hybrid. University of Khartoum Journal of Agricultural Sciences, 14(3), 343-353. Retrieved from http://onlinejournals.uofk. edu/index.php/uofkjas/article/view/2492/ 2443
Allen, R. G., Pereira, L. S., Raes, D., \& Smith, J. (1998). Crop evapotranspiration: guidelines for computing crop water requirements. Rome: FAO. Irrigation and Drainage Paper, 56.

Anastasi, U., Santonoceto, C., Giuffre, A. M., Sortino, O., \& Abbate, V. (2010). Yield performance and grain lipid composition of standard and oleic sunflower as affected by water supply. Field Crops Research, 119, 145-153. doi: 10.1016/j.fcr.2010.07.00

Andrade, F. H., Calvino, P., Cirilo, A., \& Barbieri, P. (2002). Yield responses to narrow rows depend on increased radiation interception. Agronomy Journal, 94(5), 975-980. doi: 10.2134/agronj2002.9750

Backer, R. L., Souza, A. M., Balbinot, A. A., Jr., Gallotti, J. M., \& Bavaresco, A. (2008). Desempenho de cultivares de girassol em duas épocas de plantio de safrinha no planalto norte catarinense. Scientia Agraria, 9(1), 41-48. doi: 10.5380/rsa.v9i1.10131

Biscaro, G. A., Machado, J. R., Tosta, M. S., Mendonça, V., Soratto, R. P., \& Carvalho, L. A. (2008). Adubação nitrogenada em cobertura no girassol irrigado nas condições de Cassilândia - MS. Ciência e Agrotecnologia, 32(5), 1366-1373. doi: 10.1590/ S1413-70542008000500002 
Castro, C. D., \& Farias, J. D. (2005). Ecofisiologia do girassol. Girassol no Brasil. Londrina: EMBRAPA Soja.

Cavalcante, E. G., Jr., Medeiros, J. F., Melo, T. K., Sobrinho, J. E., Bristot, G., \& Almeida, B. M. (2013). Necessidade hídrica da cultura do girassol irrigado na chapada do Apodi. Revista Brasileira de Engenharia Agrícola e Ambiental, 17(3), 261-267. Retrieved from http://www.agriambi.com.br/revista/ v17n03/v17n03a03.pdf

Companhia Nacional de Abastecimento (2018). Acompanhamento da safra brasileira de grãos. Terceiro levantamento, dezembro 2018.

Food and Agriculture Organization of the United Nations (2002). Crop water management. Sunflower. Retrieved from http://www.fao.org/nr/water/ cropinfo_sunflower.html

Flagella, Z., Rotunno, T., Tarantino, E., Di Caterina, R., \& De Caro, A. (2002). Changes in seed yield and oil fatty acid composition of high oleic sunflower (Helianthus annuus L.) hybrids in relation to the sowing date and the water regime. European Journal of Agronomy, 17(3), 221-230. doi: 10.1016/S11610301 (02)00012-6

Freitas, C. A., Silva, A. R., Bezerra, F. M., Andrade, R. R., Mota, F. S., \& Aquino, B. F. (2012). Crescimento da cultura do girassol irrigado com diferentes tipos de água e adubação nitrogenada. Revista Brasileira de Engenharia Agrícola e Ambiental, 16(10), 10311039. doi: 10.1590/S1415-4366 2012001000001

Goksoy, A. T., Demir, A. O., Turan, Z. M., \& Dagustu, N. (2004). Responses of sunflower (Helianthus annuus L.) to full and limited irrigation at different growth stages. Field Crops Research, 2(87), 167-178. doi: 10.1016/j.fcr.2003.11.004

Gomes, D. P., Bringel, J. M. M., Moraes, M. F. H., Gomes, J. J. A., \& Leite, R. M. V. B. D. (2006). Qualidade fisiológica e sanitária de sementes de girassol produzidas na região de Timon, Maranhão. Summa Phytopathologica, 32(3), 291-292. doi: $10.1590 / \mathrm{S} 0100-54052006000300016$

Gomes, E. P., Fedri, G., Ávila, M. R., Biscaro, G. A., Rezende, R. K., \& Jordan, R. A. (2012). Produtividade de grãos, óleo e massa seca de girassol sob diferentes lâminas de irrigação suplementar. Revista Brasileira de Engenharia Agrícola e Ambiental, 16(3), 237246. doi: 10.1590/S1415-43662012000300 001

Guedes, D. H., Fo., Santos, J. A., Jr., Chaves, L. H. G., Campos, V. B., \& Lima Oliveira, J. T. de. (2013).
Água disponível no solo e doses de nitrogênio no crescimento do girassol. Revista Brasileira de Agricultura Irrigada, 7(3), 201-212. doi: 10.7127/ rbai.v7n300016

Gusmão, J. M., Vidal, V. M., Soares, F. A. L., Teixeira, M. B., Cunha, F. N., Moraes, G. S.,... Amaral, A. M. (2018). Características morfológicas e produtivas de cultivares de girassol sob diferentes reposições hídricas. Global Science and Technology, 11(1), 17-24. Retrieved from https://rv.ifgoiano.edu.br/ periodicos /index.php/gst/article/view/984/584\#

Heckler, J. C. (2002). Sorgo e girassol no outono-inverno, em sistema plantio direto, no Mato Grosso do Sul, Brasil. Ciência Rural, 32(3), 517-520. doi:10.1590/ S0103-84782002000300024

Hussain, M., Farooq, S., Hasan, W., Ul-Allah, S., Tanveer, M., Farooq, M., \& Nawaz, A. (2018). Drought stress in sunflower: Physiological effects and its management through breeding and agronomic alternatives. Agricultural Water Management, 201, 152-166. doi: 10.1016/j.agwat.2018.01.028

Joner, G., Metz, P. A. M., Arboitte, M. Z., Pizzuti, L. A. D., Brondani, I. L., \& Restle, J. (2011). Aspectos agronômicos e produtivos dos híbridos de girassol (Helianthus annus L.) Helio 251 e Helio 360. Ciência Animal Brasileira, 12(2), 266-273. Retrieved from https://www.revistas.ufg.br/vet/article/ view/9697

Karam, F., Lahoud, R., Masaad, R., Kabalan, R., Breidi, J., Chalita, C., \& Rouphael, Y. (2007). Evapotranspiration, seed yield and water use efficiency of drip irrigated sunflower under full and deficit irrigation conditions. Agricultural Water Management, 90(3), 213-223. doi: 10.1016/j. agwat.2007.03. 009

Keller, J., \& Bliesner, R. D. (1990). Sprinkle and trickle irrigation. New York: van Nostrand Reinhold.

Khan, M. A., \& Akmal, M. (2016). Plant arrangement effect on the sunflower yield and yield traits in spring season crop. Sarhad Journal of Agriculture, 32(3), 151-155. doi: 10.17582/journal.sja/2016.32.3.151. 155

Li, J., Qu, Z., Chen, J., Yang, B., \& Huang, Y. (2019). Effect of planting density on the growth and yield of sunflower under mulched drip irrigation. Water, 11(752), 1-14. doi: 10.3390/w11040752

Porto, W. S., Carvalho, C. G. P. de, \& Pinto, R. J. B. (2007). Adaptabilidade e estabilidade como critérios para seleção de genótipos de girassol. Pesquisa Agropecuária Brasileira, 42(4), 491-499. doi: 10.1590/ S0100-204X2007000400006 
Poursakhi, N., \& Khajehpour, M. R. (2012). Effect of planting pattern and plant density on yield and yield components of sunflower, Hisun-36 Hybrid. JCPP, 2(5), 1-12. Retrieved from https://jcpp.iut.ac.ir/ browse.php?a_id=1665\&slc_lang=en\&sid=1\&print case $=1 \& \mathrm{hbnr}=1 \& \mathrm{hmb}=1$

Reddy, S., \& Amorim, M. D. S., Neto. (1983). Dados da precipitação, evaporação potencial, radiação solar global de alguns locais e classificação climática do Nordeste do Brasil. Petrolina: Empresa Brasileira de Pesquisa Agropecuária-CPATSA.

Santos, E. R., Barros, H. B., Capone, A., Ferraz, E. C., \& Fidelis, R. R. (2012). Effects of sowing periods on sunflower cultivars in the South of the State of Tocantins. Revista Ciência Agronômica, 43(1), 199206. doi: 10.1590/S1806-66902012000100025

Schwerz, T., Jakelaitis, A., Teixeira, M. B., Soares, F. A., \& Tavares, C. J. (2015). Produção de girassol cultivado após soja, milho e capim-marandu, com e sem irrigação suplementar. Revista Brasileira de Engenharia Agricola e Ambiental, 19(5), 470-475. doi: 10.1590/1807-1929/agriambi.v19n5p470-475

Silva, A. G., Pires, R., Morães, E. B., Oliveira, A. C. B., \& Carvalho, C. G. P. (2009). Desempenho de híbridos de girassol em espaçamentos reduzidos. Ciências Agrárias, 30(1), 31-38. doi: 10.5433/1679-0359.2009v30n1p31

Silva, M. L. O., Faria, M. A., Morais, A. R., Andrade, G. P., \& Lima, E. M. D. C. (2007). Crescimento e produtividade do girassol cultivado na entressafra com diferentes lâminas de água. Revista Brasileira de Engenharia Agrícola e Ambiental, 11(5), 482488. doi: 10.1590/S1415-43662007000500006
Silva, P. C. G., Moura, M. S. B., Kill, L. H. P., Brito, L. T. L., Pereira, L. A., Sá, I. B., Guimarães, C., Fº (2010). Caracterização do semiárido brasileiro: Fatores naturais e humanos. In I. B. Sá, \& P. C. G. Silva, Semiárido brasileiro: pesquisa, desenvolvimento $e$ inovação (pp. 17-48). Petrolina: EMBRAPA Semiárido.

Simões, W. L., Coelho, D. S., Souza, M., Drumond, M., Assis, J. S. de, \& Lima, J. A. (2016). Aspectos morfofisiológicos do girassol irrigado por gotejamento no Submédio São Francisco. Irriga, 1(1), 66-77. doi: 10.15809/irriga.2016v1n1p66-77

Simões, W. L., Drumond, M. A., Oliveira, A. R., Gonçalves, S. L., \& Guimarães, M. J. M. (2018). Morphophysiological and productive responses of sunflower varieties to irrigation. Revista Caatinga, 31(1), 143-150. doi: 10.1590/1983-21252018v31n117rc

Smiderle, O. J., Mourão, M., Jr., \& Gianluppi, D. (2005). Avaliação de cultivares de girassol em savana de Roraima. Acta Amazônica, 35(3), 331-336. doi: 10.1590/S0044-59672005000300004

Taiz, L., Zeiger, E., Møller, I. M., \& Murphy, A. (2017). Fisiologia e desenvolvimento vegetal. Artmed Editora.

Travassos, K. D., Gheyi, H. R., Soares, F. A. L., Barros, H. M. M., Dias, N. S., Uyeda, C.A., \& Silva, F. V. (2012). Crescimento e desenvolvimento de variedades de girassol irrigado com água salina. Irriga, 1(1), 324339. doi: 10.15809/irriga.2012v1n01p324

Zarea, M. J., Ghalavand, A., \& Daneshian, J. (2005). Effect of planting patterns of sunflower on yield and extinction coefficient. Agronomy for Sustainable Development, 25(4), 513-518. Retrieved from https:// hal.archives-ouvertes.fr/hal-00886308/ 